\title{
Skew deviation and retinal photography
}

Figure 1 Nonmydriatic retinal photography (i.e., no pharmacologic pupil dilation required)

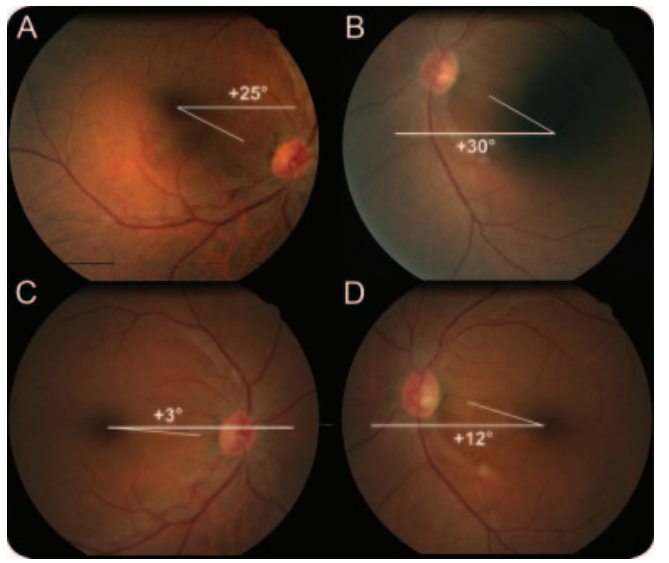

Ocular cyclotorsion measured at admission (top) and after 3 days (bottom, right $[A, C]$ and left [B, D] eyes).

Figure 2 Diffusion-weighted images showing a focal acute ischemic stroke located in the pons

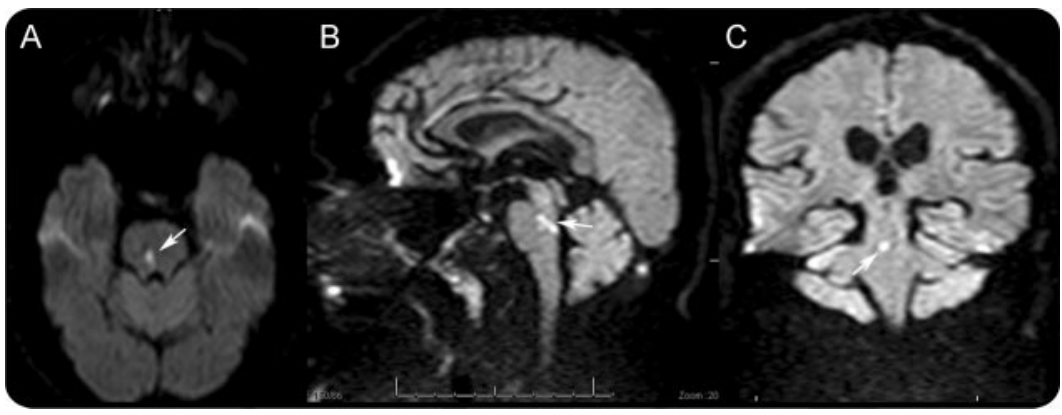

Axial (A), sagittal (B), and coronal (C) images.

A 50-year-old man was admitted for the acute onset of vertical diplopia worse on left gaze. The right eye appeared hypertropic. Either right fourth nerve palsy or skew deviation was possible..$^{1,2}$ Nonmydriatic retinal photography revealed an excyclotorsion of the hypotropic eye associated with incyclotorsion of the hypertropic eye (figure 1, A and B) providing a key element for skew deviation. In case of an acquired fourth nerve palsy, an excyclotorsion of the hypertropic eye would have been expected. MRI showed a pontine ischemic stroke (figure 2). Nonmydriatic retinal photography is a noninvasive examination that can help to distinguish fourth nerve palsy from skew deviation.

Damien Biotti, MD, Samuel Bidot, MD, Paris, France

Author contributions: Dr. Biotti: drafting/revising the manuscript, analysis or interpretation of data. Dr. Bidot: drafting/revising the manuscript, acquisition of data.

Disclosure: The authors report no disclosures.

Address correspondence and reprint requests to Dr. Damien Biotti, Department of Neurology, Fondation Ophtalmologique Adolphe de Rothschild, 25 Rue Manin, 75019 Paris,France; dbiotti@hotmail.com

1. Wong AM. Understanding skew deviation and a new clinical test to differentiate it from trochlear nerve palsy. J AAPOS 2010;14:61-67.

2. Brodsky MC, Donahue SP, Vaphiades M, Brandt T. Skew deviation revisited. Surv Ophthalmol 2006;51:105-128. 


\title{
Neurology
}

\author{
Skew deviation and retinal photography \\ Damien Biotti and Samuel Bidot \\ Neurology 2011;77;2137 \\ DOI 10.1212/WNL.0b013e31823d7698
}

This information is current as of December 12, 2011

\section{Updated Information \&} Services

References

Subspecialty Collections

Permissions \& Licensing

Reprints including high resolution figures, can be found at: http://n.neurology.org/content/77/24/2137.full

This article cites 2 articles, 0 of which you can access for free at: http://n.neurology.org/content/77/24/2137.full\#ref-list-1

This article, along with others on similar topics, appears in the following collection(s):

\section{All Cerebrovascular disease/Stroke}

http://n.neurology.org/cgi/collection/all_cerebrovascular_disease_strok e

All Imaging

http://n.neurology.org/cgi/collection/all_imaging

Clinical neurology examination

http://n.neurology.org/cgi/collection/clinical_neurology_examination Diplopia (double vision)

http://n.neurology.org/cgi/collection/diplopia_double_vision Ocular motility

http://n.neurology.org/cgi/collection/ocular_motility

Information about reproducing this article in parts (figures,tables) or in its entirety can be found online at:

http://www.neurology.org/about/about_the_journal\#permissions

Information about ordering reprints can be found online:

http://n.neurology.org/subscribers/advertise

Neurology ${ }^{\circledR}$ is the official journal of the American Academy of Neurology. Published continuously since 1951 , it is now a weekly with 48 issues per year. Copyright Copyright $@ 2011$ by AAN Enterprises, Inc.. All rights reserved. Print ISSN: 0028-3878. Online ISSN: 1526-632X.

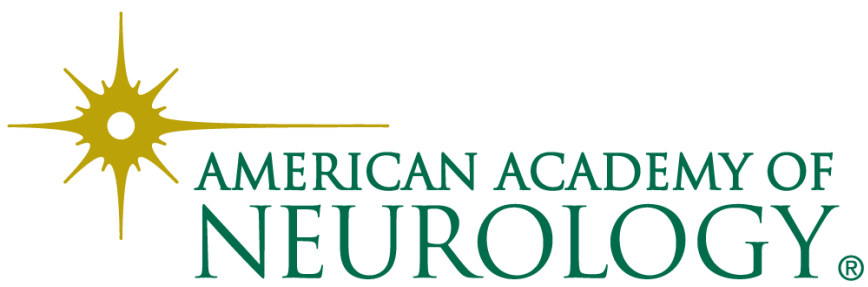

